\title{
PENDAPATAN DAN TINGKAT KESEJAHTERAAN RUMAH TANGGA PETAMBAK UDANG VANAME EKS PLASMA PT CENTRALPERTIWI BAHARI DESA BRATASENA ADIWARNA
}

\author{
(Income and Household Welfare of Vaname Cultivators Ex-plasma of PT Centralpertiwi Bahari \\ at Bratasena Adiwarna Village)
}

Cindy Puri Andini, Wuryaningsih Dwi Sayekti, Fembriarti Erry Prasmatiwi

Jurusan Agribisnis, Fakultas Pertanian, Universitas Lampung, Jl. Prof. Dr. Soemantri Brodjonegoro No. 1 Bandar Lampung, 35145, e-mail: andinicindy@gmail.com

\begin{abstract}
This research aims to analyze household income, welfare, and factors that influence the household welfare of vaname cultivators ex-plasma PT Centralpertiwi Bahari. Data of this research was collected in Bratasena Adiwarna village in February 2018. Samples in this research were 70 shrimp cultivators households. Determination of samples with simple random sampling. Primary data was obtained by interviewing respondens, while secondary data was obtained from several related institution. Household income consists of shrimp income, nonshrimp, off-farm and nonfarm income. Household welfare level was analyzed by the Sajogyo criteria and poverty line according to BPS Lampung (2017). The factors that influence household welfare was analyzed by binary logistic regression. The research result showed that the average shrimp income in period I, II, and III were Rp7,986,264; Rp13,868,109; and Rp27,334,963; average household income was Rp64,902,569.00 per year, which was obtained from 70 percent of shrimp income, 10 percent of nonshrimp income, 2 percent of off-farm income, and 18 percent of nonfarm income. The household welfare level based on the Sajogyo indicator showed that 37 percent of household were in moderate and 63 percent were in decent living class, while the BPS poverty line shows that all of households were classified as nonpoor. The level of household welfare of ex-plasma PT Centralpertiwi Bahari was influenced by household income, and household dependents.
\end{abstract}

Key words: income, vaname shrimp cultivator, welfare

\section{PENDAHULUAN}

Subsektor perikanan merupakan salah satu dari subsektor pertanian yang memiliki potensi besar untuk dikembangkan di Indonesia. Usaha perikanan budi daya terdiri dari budi daya laut, tambak, kolam, keramba, jaring apung, jaring tancap, dan sawah. Produksi perikanan budi daya terbesar di Provinsi Lampung dihasilkan oleh kolam dan tambak sebagai produksi terbesar ke dua dengan jumlah produksi berturut-turut 55.350 ton dan 53.076 ton per tahun (BPS 2015).

Kabupaten Tulang Bawang merupakan salah satu kabupaten yang ada di Provinsi Lampung yang menjadi sentra produksi usaha tambak dengan jumlah produksi 28.204 ton per tahun (BPS Kabupaten Tulang Bawang 2017). Komoditas usaha tambak yang dibudidayakan adalah udang vaname. Menurut Kementerian Kelautan dan Perikanan (2012) Provinsi Lampung menjadi sentra penghasil produksi udang vaname terbesar di Indonesia dengan jumlah produksi 72.051 ton per tahun. Menurut Dinas Kelautan dan Perikanan
Provinsi Lampung (2016), Kabupaten Tulang Bawang menjadi penyumbang produksi udang vaname terbesar bagi Provinsi Lampung dengannilai produksi 27.440 ton.

Desa Bratasena Adiwarna merupakan salah satudesa yang ada diKabupaten Tulang Bawang yang memproduksi udang vaname. Pada tahun 1994 sampai dengan 2016 petambak di Desa Bratasena Adiwarna melakukan kemitraan dengan perusahaan. Perusahaan yang menjalin hubungan mitra dengan plasma dalam membudidayakan udang vaname adalah PT Centralpertiwi Bahari (PT CPB).

PT Centralpertiwi Bahari (CPB) adalah anak perusahaan dari PT Central Proteina Prima (CPP) yangbergerak dalam produksi udang beku dan berbagai olahan udang ekspor (CPP 2016). Perusahaan ini melakukan kemitraan dengan para plasma dalam menjalankan kegiatannya. Seluruh mitra plasma diberikan subsidi sebagai jaminan kehidupan yang layak oleh perusahaan, meliputi gaji, tunjangan natura, dan perumahan. 
Berdasarkan informasi yang diperoleh dari petambak udang vaname eks plasma PT CPB, pada tahun 2009 muncul penyakit yang menyerang udang sehingga terjadi gagal panen di sebagian besar tambak. Hal tersebut mengakibatkan penurunan produksi secara drastis. Pada tahun 2011 terjadi aksi demonstrasi oleh plasma terhadap PT CPB atas penuntutan kenaikan gaji. Akan tetapi PT CPB tidak dapat memenuhi tuntutan tersebut karena kondisi keuangan perusahaan yang belum stabil akibat terjadi penurunan produksi. $\mathrm{Hal}$ inilah yang menyebabkan terjadinya pemutusan hubungan mitra, sehingga mitra plasma berubah menjadi petambak mandiri. Selain itu, pola budi daya udang berubah dari intensif menjadi semi intensif.

Perubahan pola budi daya menyebabkan perubahan penggunaan sarana produksi. Kondisi perekonomian petambak mempengaruhi ketersediaan sarana produksi. Hal ini akan berdampak pada hasil produksi udang sehingga dapat mempengaruhi pendapatan rumah tangga petambak. Besarnya pendapatan rumah tangga akan berpengaruh terhadap tingkat kesejahteraan.

Hasil budi daya udang vaname digunakan sebagai sumber pendapatan utama bagi petambak di Desa Bratasena Adiwarna. Semakin rendah pendapatan rumah tangga petambak maka semakin dekat pula rumah tangga petambak dengan kemiskinan. Berdasarkan masalah yang telah diuraikan maka tujuan dari penelitian ini yaitu menghitung pendapatan udang, pendapatan rumah tangga, menganalisis tingkat kesejahteraan rumah tangga, dan mengkaji faktor-faktor yang mempengaruhi tingkat kesejahteraan rumah tangga petambak udang vaname eks plasma PT Centralpertiwi Bahari.

\section{METODE PENELITIAN}

Metode penelitian yang digunakan dalam penelitian ini adalah survai. Penelitian ini dilakukan di Desa Bratasena Adiwarna. Penentuan lokasi penelitian dilakukan secara sengaja (purposive) dengan pertimbangan bahwa terdapat kasus pemutusan hubungan mitra antara PT CPB dengan petambak yang terjadi kurang lebih satu tahun yang lalu dan seluruh penduduk di Desa Bratasena Adiwarna bermatapencaharian utama sebagai petambak udang vaname. Sampel dari penelitian ini adalah rumah tangga petambak udang vaname. Responden dari penelitian ini adalah kepala rumah tangga (petambak) dan istri petambak. Pengumpulan data dilakukan pada bulan Februari 2018.

Penentuan jumlah sampel dilakukan dengan menggunakan rumus Irianto, dan Mardikanto (2012) .

$\mathrm{n}=\frac{\mathrm{NZ} Z^{2} \sigma^{2}}{\mathrm{NZ}^{2} \sigma^{2}+\mathrm{Z}^{2} \sigma^{2}}$

Keterangan :

$\mathrm{n}=$ Ukuran sampel

$\mathrm{N}=$ Populasi petambak (1.120)

$Z=$ Derajat kepercayaan Z $(95 \%=1,96)$

$\sigma^{2}=$ Varian sampel $(5 \%=0,05)$

$\delta=$ Standar deviasi $(5 \%=0,05)$

Berdasarkan rumus tersebut diperoleh sampel sebanyak 70 rumah tangga petambak. Teknik pengambilan sampel yang digunakan adalah proportional random sampling. Pemilihan teknik pengambilan sampel tersebut karena jumlah petambak dalam tiap dusun tidak sama, sehingga dipilih teknik tersebut agar penyebaran responden dapat merata.

Berdasarkan teknik pengambilan sampel tersebut diperoleh responden sebanyak 70 rumah tangga petambak yang tersebar dalam enam dusun. Jumlah sampel di dusun I hingga dusun VI berturut-turut adalah $5,15,16,12,10$, dan 12 rumah tangga petambak udang vaname

Pendapatan udang dapat diketahui dengan menggunakan rumus Soekartawi (2002).

$\pi=$ TR-TC

$\pi=(\mathrm{Y} . \mathrm{Py})-(\mathrm{Xi} \cdot \mathrm{Pi})$

Keterangan :

$\pi=$ Keuntungan $(\mathrm{Rp})$

$\mathrm{Y}=$ Produksi udang $(\mathrm{kg})$

Py $=$ Harga udang (Rp)

$\mathrm{Xi}=$ Faktor produksi $\mathrm{i}$

$\mathrm{Pi}=$ Harga faktor produksi $\mathrm{i}(\mathrm{Rp})$

Biaya terbagi menjadi biaya tunai dan biaya diperhitungkan. Biaya tunai meliputi biaya benih udang, pakan kapur, obat-obatan, solar, penjualan, transportasi, air, pajak, dan tenaga kerja luar keluarga. Biaya diperhitungkan meliputi biaya sewa tambak, penyusutan alat, dan tenaga kerja dalam keluarga. 
Menurut Soekartawi (2006), untuk mengetahui suatu usahatani menguntungkan atau tidak dapat diketahui dengan analisis Return Cost Ratio (R/C).

$\mathrm{R} / \mathrm{C}=\mathrm{PT} / \mathrm{BT}$

Keterangan:

$\mathrm{R} / \mathrm{C}=$ nisbah penerimaan dan biaya

$\mathrm{PT}=$ penerimaan total $(\mathrm{Rp})$

$\mathrm{BT}=$ biaya total $(\mathrm{Rp})$

Pendapatan rumah tangga petambak udang vaname dapat diketahui dengan menggunakan rumus sebagai berikut.

Prt $=\mathrm{P}_{\text {udang }}+\mathrm{P}_{\text {nonudang }}+\mathrm{P}_{\text {off farm }}+\mathrm{P}_{\mathrm{n}}$

Keterangan:

Prt $=$ Pendapatan rumah tangga petambak

$\mathrm{P}_{\text {udang }}=$ Pendapatan dari budidaya udang vaname

$\mathrm{P}_{\text {nonudang }}=$ Pendapatan dari usahatani diluar budidaya udang

$\mathrm{P}_{\text {off farm }}=$ Pendapatan pertanian diluar usahatani

$\mathrm{P}_{\text {non farm }}=$ Pendapatan dari kegiatan diluar sektor pertanian

Kontribusi pendapatan udang dapat diketahui dengan rumus sebagai berikut.

Kontribusi $=\frac{\text { Pendapatan } \mathrm{udang}}{\text { Pendapatan RT }} \times 100 \%$

Tingkat kesejahteraan diukur berdasarkan indikator kesejahteraan Sajogyo (1996) dan garis kemiskinan menurut BPS Provinsi Lampung (2017). Menurut Sajogyo (1996) kesejahteraan dapat diukur melalui pendekatan pengeluaran yang diseterakan dengan nilai tukar beras yang berlaku. Secara matematis pengeluaran (C) dapat dihitungdengan rumus berikut .

$\mathrm{C} /$ kapita/tahun $(\mathrm{Rp})=\frac{\mathrm{c}}{\sum \text { anggota keluarga }} \ldots \ldots . .(6)$

$\mathrm{C} / \mathrm{kapita} /$ setara beras $(\mathrm{kg})=$

( $\frac{\mathrm{c}}{\text { Kapita }} /$ tahun $):$ harga beras

Klasifikasi kemiskinan menurut indikator Sajogyo digolongkan sebagai berikut.

(1) Paling miskin, jika C per anggota keluarga $\geq 180 \mathrm{~kg}$ setara nilai beras/tahun.
(2) Miskin sekali, jika C per anggota keluarga antara $181-240 \mathrm{~kg}$ setara nilai beras/tahun.

(3) Miskin, jika $\mathrm{C}$ per anggota keluarga antara $241-320 \mathrm{~kg}$ setara nilai beras/tahun.

(4) Nyaris miskin, jika C antara $321-480 \mathrm{~kg}$ setara nilai beras/tahun.

(5) Cukup, jika $\mathrm{C}$ per anggota keluarga antara 481 $-960 \mathrm{~kg}$ setara nilai beras/tahun.

(6) Hidup layak, jika $\mathrm{C}$ per anggota keluarga lebih dari $960 \mathrm{~kg}$ setara nilai beras/tahun

Menurut BPS Provinsi Lampung (2017) garis kemiskinan masyarakat Lampung adalah Rp384.882,00 per kapita per bulan. Sedangkan untuk garis kemiskinan masyarakat Kabupaten Tulang Bawang adalah Rp373.681,00 per kapita per bulan.

Faktor-faktor yang mempengaruhi kesejahteraan rumah tangga petambak dapat diketahui dengan menggunakan analisis logistic regression. Penggunaan regresi logistik bertujuan untuk mengetahui pengaruh variabel pendapatan rumah tangga (X1), jumlah tanggungan rumah tangga (X2), pendidikan (X3), pengalaman budidaya (X4), dan usia responden (X5) terhadap tingkat kesejahteraan rumah tangga petambak. Menurut Yuwono (2005) model logit dapat dinyatakan sebagai berikut.

$\mathrm{Pi}=\mathrm{F}(\mathrm{Zi})=\mathrm{F}(\alpha+\beta \mathrm{Xi})$

Sehinga model regresi yang digunakan dalam peneliitian ini adalah:

$\mathrm{Zi}=\mathrm{Ln}[\mathrm{Pi} / 1-\mathrm{Pi}]=\alpha+\beta 1 \mathrm{X} 1+\beta 2 \mathrm{X} 2+\beta 3 \mathrm{X} 3+$ $\beta 4 \mathrm{X} 4+\beta 5 \mathrm{X} 5$

Keterangan:

$\mathrm{Zi}$ = Peluang rumah tangga sejahtera $\quad(1=$ Sejahtera, $0=$ Belum sejahtera)

$\mathrm{Pi}=$ Peluang anggota untuk sejahtera bila $\mathrm{Xi}$ diketahui

$\alpha=$ Intersep

$\beta \mathrm{i}=$ Koefisien variabel bebas

$\mathrm{X} 1=$ Pendapatan rumah tangga $(\mathrm{Rp})$

$\mathrm{X} 2$ = Jumlah tanggungan keluarga (orang)

$\mathrm{X} 3=$ Pendidikan (tahun)

$\mathrm{X} 4=$ Pengalaman budidaya udang (tahun)

$\mathrm{X} 5=$ Usia responden (tahun)

Likelihood Ratio (LR) dapat digunakan untuk melakukan uji serentak estimasi model logit yang berfungsi untuk menguji apakah variabel independen secara bersama-sama mempengaruhi variabel dependen. Uji parsial menggunakan Wald 
Test dilakukan untuk mengetahui seberapa baik model dapat menjelaskan hubungan antara variabel dependen dan independen. Odds ratio digunakan untuk mengukur peluang seberapa besar pengaruh variabel independen terhadap variabel dependen. Nilai odds ratio ditunjukkan dengan nilai $\operatorname{Exp}(\mathrm{B})$ pada SPSS (Sarwono 2014).

\section{HASIL DAN PEMBAHASAN}

\section{Karakteristik Responden}

Rata-rata usia petambak adalah 48 tahun dengan rentang usia 35 sampai 58 tahun. Sebagian besar petambak udang vaname memiliki jumlah tahun sukses belajar antara 10 sampai 12, artinya petambak telah menempuh pendidikan hingga jenjang SMA. Rata-rata pengalaman budi daya petambak udang vaname di Desa Bratasena Adiwarna adalah 21 sampai 30 tahun. Sebagian besar $(94,44 \%)$ rumah tangga petambak memiliki jumlah anggota keluarga 3 sampai 4 jiwa.

Sebesar 88,58 persen petambak memiliki pekerjaan sampingan sebagai petani nonudang dan buruh panen, sedangkan 11,42 persen petambak memiliki pekerjaan sampingan sebagai pegawai kelurahan dan karyawan Koperasi Bima Utama Sakti. Luas tambak yang dimiliki oleh petambak adalah 0,5 ha dengan status kepemilikan milik sendiri. Petambak di Desa Bratasena Adiwarna diberikan satu petak tambak per orang dari PT CPB untuk dikelola. Kepemilikan tambak telah sepenuhnya dikuasai oleh petambak masing-masing.

\section{Pendapatan Usaha Budi Daya Udang Vaname}

Budi daya udang vaname di Desa Bratasena Adiwarna merupakan budi daya semi intensif. Modal usaha budi daya udang vaname adalah modal sendiri. Budi daya udang vaname berlangsung selama tiga periode dalam satu tahun dengan masa pemeliharaan 2 hingga 3 bulan per periode. Periode I dilakukan pada bulan Mei, Juni, dan Juli. Periode II dilakukan pada bulan September, Oktober, dan November. Periode III dilakukan pada bulan Januari, Februari, dan Maret. Bulan Agustus, Desember, dan April merupakan periode pergantian dimana tambak dibiarkan dalam keadaan kering sebelum dilakukannya budi daya periode berikutnya. Kegiatan dalam budi daya meliputi persiapan tambak, penebaran benih, pemeliharaan, panen, dan pasca panen.

Petambak memperoleh benih udang dari Desa Way Dente. Harga benih udang Rp40,00 per ekor.
Ukuran benih yang ditebar adalah PL (Post Larva) 10-PL12 dengan berat 0,001 gram per ekor. Pada ukuran tersebut, benih udang sudah memiliki organ insang yang sempurna sehingga kemungkinan udang untuk bertahan hidup di tambak relatif tinggi.

Merupakan yang digunakan oleh petambak udang vaname di Desa Bratasena Adiwarna hanya Marine dan Irawan. Petambak membeli pakan di Koperasi Bima Utama Sakti. Harga pakan Marine adalah Rp11.000,00 per kg, sedangkan harga pakan Irawan adalah Rp15.000,00 per kg. Penggunaan pakan Marine lebih besar dibandingkan dengan pakan Irawan karena harga pakan Marine yang lebih murah.

Kapur yang digunakan oleh petambak adalah dolomit dan $\mathrm{CaO}_{2}$. Akan tetapi penggunaan dolomit jauh lebih besar dibandingkan dengan $\mathrm{CaO}_{2}$ karena harga dolomit yang lebih murah yaitu Rp700,00 per kg sedangkan harga $\mathrm{CaO}_{2}$ adalah Rp1.700,00 per kg.

Menurut Badan Penelitian dan Pengembangan Kelautan dan Perikanan (2014), penggunaan obatobatan dan pupuk pada budi daya udang vaname adalah saponin, probiotik, pupuk organik (1.000 sampai $2.000 \mathrm{~kg}$ per hektar), pupuk urea (100 sampai $200 \mathrm{~kg}$ per hektar), dan SP-36 (100 kg per hektar). Obat-obatan yang digunakan dalam budi daya udang vaname di Desa Bratasena Adiwarna adalah Bintan, Kupri Sulfat, probiotik, Super Ps, klorin, Pondfos, dan Saponin. Petambak belum menggunakan pupuk organik, urea, maupun SP-36 karena kurangnya pengetahuan.

Peralatan yang digunakan dalam budi daya udang adalah sampan, karpet, mesin diesel, kincir, ancho, benang BSD, paralon, dan kabel empat ulir. Penggunaan kincir di Desa Bratasena Adiwarna adalah 3 sampai 4 set per 0,5 ha tambak. Keterbatasan jumlah kincir ini menyebabkan kurang maksimalnya produksi udang. Karena semakin banyak benih udang yang ditebar maka semakin banyak jumlah kincir yang diperlukan. Biaya dan pendapatan usaha budi daya udang disajikan pada Tabel 1. Berdasarkan data pada Tabel 1 diketahui bahwa dari periode I sampai periode III nilai sarana produksi tambak mengalami peningkatan. Peningkatan tersebut disebabkan oleh meningkatnya kepemilikan modal petambak sehingga petambak mampu membeli mesin diesel dan menebar benih dalam jumlah yang lebih banyak dibandingkan dengan periode sebelumnya. 
JIIA, VOLUME 8 No. 1, FEBRUARI 2020

Tabel 1. Pendapatan dan R/C budi daya udang vaname di Desa Bratasena Adiwarna

\begin{tabular}{lrrr}
\hline & \multicolumn{3}{c}{ Nilai (Rp) per 0.5 ha } \\
\cline { 2 - 4 } & \multicolumn{3}{c}{ Periode budi daya udang vaname } \\
\cline { 2 - 4 } & \multicolumn{1}{c}{ Periode I } & Periode II & Periode III \\
\hline Udang vaname (kg) & $21.770 .700,00$ & $32.097 .700,00$ & $44.459 .385,71$ \\
Biaya Produksi & & & $17.125 .581,28$ \\
a. Biaya Tunai & $9.626 .991,90$ & $13.998 .907,49$ & $2.444 .571,43$ \\
Benih & $1.382 .285,71$ & $2.072 .571,43$ & $8.634 .928,57$ \\
Pakan: & $4.776 .285,71$ & $6.651 .500,00$ & $2.885 .980,85$ \\
Obat-obatan & $1.918 .871,43$ & $2.484 .884,47$ & $217.600,00$ \\
Kapur & $143.757,14$ & $185.092,86$ & $942.616,43$ \\
Solar & $162.285,71$ & $848.020,00$ & $709.214,29$ \\
Penjualan & $406.642,86$ & $551.071,43$ & $657.217,34$ \\
TKLK & $337.439,52$ & $582.457,78$ & $91.785,71$ \\
Transportasi & $75.757,14$ & $81.642,86$ & $500.000,00$ \\
Air & $500.000,00$ & $500.000,00$ & $41.666,67$ \\
Pajak & $41.666,67$ & $41.666,67$ & $4.296 .797,34$ \\
b.Biaya Diperhitungkan & $4.157 .306,58$ & $4.230 .024,42$ & $1.475 .972,91$ \\
TKDK & $1.336 .482,16$ & $1.409 .199,99$ & $1.802 .824,43$ \\
Penyusutan & $1.820 .824,43$ & $1.802 .824,43$ & $1.000 .000,00$ \\
Sewa & $1.000 .000,00$ & $1.000 .000,00$ & $21.422 .378,62$ \\
\hline Total Biaya & $13.784 .298,49$ & $18.228 .931,90$ & $27.333 .804,43$ \\
\hline Pendapatan Tunai & $12.143 .798,10$ & $18.098 .792,51$ & $23.037 .007,09$ \\
Pendapatan Total & $7.986 .401,51$ & $13.868 .768,10$ & 2,60 \\
\hline R/C Tunai & 2,26 & 2,29 & 2,08 \\
R/C Total & 1,58 & 1,76 & \\
\hline
\end{tabular}

Biaya yang paling besar dikeluarkan dalam kegiatan budi daya udang vaname adalah biaya pakan (30,30 persen). Penelitian ini sejalan dengan penelitian Susanti, Lestari, dan Kasymir (2017) yang menunjukkan bahwa biaya pakan pada budi daya ikan patin di Kecamatan Kota Gajah memiliki kontribusi terbesar terhadap biaya total (67 persen dari biaya total). Hal ini membuktikan bahwa biaya pakan sangat mendominasi dalam kegiatan budi daya perikanan.

Usia pemeliharaan udang vaname di Desa Bratasena Adiwarna berkisar antara 22 sampai 82 hari. Udang memiliki nilai jika usia pemeliharannya lebih dari 66 hari, hal ini karena harga jual udang vaname sesuai dengan Mean Body Weight (MBW). Semakin besar MBW udang maka semakin tinggi pula harga jualnya.

Berdasarkan Tabel 1, R/C atas biaya tunai maupun atas biaya total memiliki nilai lebih dari satu. Artinya usaha budi daya udang vaname pada periode I, II, dan III menguntungkan untuk dijalankan. Selain itu pendapatan udang atas biaya tunai maupu pendapatan atas biaya total terbesar adalah pada periode III. Peningkatan $\mathrm{R} / \mathrm{C}$ rasio maupun pendapatan disebabkan oleh meningkatnya modal yang dimiliki petambak sehingga jumlah benih yang ditebar lebih banyak dan penggunaan sarana produksi tambak lebih maksimal dari periode sebelumnya. Selain itu, pada periode III serangan dan penyebaran penyakit terhadap udang lebih rendah bila dibandingkan dengan periode sebelumnya.

Nilai R/C pada penelitian ini lebih kecil bila dibandingkan dengan hasil penelitian Pulungan, Fauzia, dan Emalisa (2015). Hasil penelitian tersebut menunjukkan bahwa $\mathrm{R} / \mathrm{C}$ rasio atas biaya tunai petambak udang vaname di Kecamatan Pangkalan Susu adalah 2,70. Akan tetapi perbedaan nilai $\mathrm{R} / \mathrm{C}$ rasio atas biaya tunai antara kedua penelitian tersebut tidak terlalu signifikan dan sama-sama memiliki nilai $\mathrm{R} / \mathrm{C}$ rasio lebih dari satu. Oleh karena itu dapat disimpulkan bahwa usaha budi daya udang vaname menguntungkan untuk dijalankan

\section{Pendapatan Rumah Tangga}

Pendapatan rumah tangga petambak udang vaname bersumber dari pendapatan udang, pendapatan usahatani nonudang, pendapatan off farm, dan pendapatan nonfarm. Usaha budi daya udang vaname merupakan pendapatan utama bagi rumah tangga petambak udang vaname. Akan tetapi, peningkatan kebutuhan dan keinginan menyebabkan petambak mencari sumber pendapatan lain untuk meningkatkan pendapatan.

Pendapatan usahatani nonudang diperoleh dari usahatani padi, singkong, jagung, ternak ayam kampung, dan usahatani tanaman di pekarangan rumah. Pendapatan off farm rumah tangga petambak diperoleh dari hasil buruh panen, dan 
berdagang sayuran. Pendapatan nonfarm yang diperoleh petambak berasal dari pegawai kelurahan, karyawan atau karyawati, karyawan KBUS, dan penjahit. Pendapatan rumah tangga petambak udang vaname di Desa Bratasena Adiwarna disajikan dalam Tabel 2.

Berdasarkan data pada Tabel 2 dapat dilihat bahwa pendapatan budi daya udang berkontribusi paling besar terhadap pendapatan rumah tangga yaitu 70 persen. Hal tersebut karena usaha budi daya udang merupakan usaha utama bagi rumah tangga petambak di Desa Bratasena Adiwarna.

\section{Kesejahteraan Rumah Tangga Petambak}

Pengukuran tingkat kesejahteraan rumah tangga petambak dilakukan dengan menggunakan Indikator Sajogyo (1996) dengan mengonversikan total pengeluaran rumah tangga per kapita per tahun dengan beras. Harga beras yang digunakan adalah harga beras rata-rata yang dikonsumsi oleh rumah tangga petambakudang vaname di Desa Bratasena Adiwarna.

Pada penelitian ini pengeluaran pangan dikelompokkan atas padi-padian, umbi-umbian, minyak dan lemak, pangan hewani, kacangkacangan, biji berminyak, gula, sayur bewarna, sayur tak bewarna, sayur buah, buah, bumbu dapur, minuman, dan jajanan. Pengeluaran nonpangan dikelompokkan atas rokok, kesehatan, pendidikan, listrik, telepon atau handphone, perabotan rumah, perbaikan rumah, pakaian, bensin, gas, transportasi, pajak, keperluan bayi, perhiasan, kebersihan badan, kosmetik, dan kebutuhan lainnya.

Pengeluaran rumah tangga petambak udang vaname memiliki kisaran antara Rp19.154.400,00 sampai Rp61.058.400,00 per tahun dengan ratarata pengeluaran Rp41.290.343,00 per rumah tangga per tahun. Pengeluaran rata-rata rumah tangga per tahun terdiri dari pengeluaran pangan sebesar Rp17.254.985,71 (41,78 persen) dan

Tabel 2. Pendapatan rumah tangga petambak udang vaname di Desa Bratasena Adiwarna

\begin{tabular}{lrr}
\hline Sumber Pendapatan & $\begin{array}{c}\text { Pendapatan } \\
\text { (Rp/tahun) }\end{array}$ & $\%$ \\
\hline Budi daya udang & $44.893 .668,00$ & 70 \\
Usahatani nonudang & $6.363 .177,00$ & 10 \\
Off farm & $1.260 .000,00$ & 2 \\
Nonfarm & $12.385 .714,00$ & 18 \\
\hline Total & $64.902 .569,00$ & 100 \\
\hline
\end{tabular}

pengeluaran nonpangan sebesar Rp24.035.357,14 $(58,21$ persen $)$.

Berdasarkan kriteria Sajogyo (1996), rumah tangga petambak udang vaname di Desa Bratasena Adiwarna tergolong menjadi dua golongan yaitu cukup dan hidup layak. Golongan cukup memiliki pengeluaran Rp7.306.850,00 sampai Rp10.785.466,67 atau setara dengan 610,67 sampai $901,40 \mathrm{~kg}$ beras per kapita per tahun. Golongan hidup layak memiliki pengeluaran Rp11.551.650,00 sampai Rp15.264.600,00 atau setara dengan 962,42 sampai $1.275,74 \mathrm{~kg}$ beras per kapita per tahun. Sebesar 37 persen petambak berada pada golongan cukup dan 63 persen berada pada golongan hidup layak. Untuk selanjutnya pada penelitian ini kriteria cukup disebut dengan rumah tangga belum sejahtera dan kriteria hidup layak disebut sebagai rumah tangga sejahtera. Hasil penelitian ini berbeda dengan hasil penelitian Fadilah, Abidin, dan Kulsum (2014) yang menyatakan bahwa kesejahteraan rumah tangga nelayan obor masuk dalam golongan nyaris miskin $(9,3 \%)$, cukup $(74,42 \%)$, dan hidup layak $(16,28 \%)$. Hal ini menunjukkan bahwa rumah tangga petambak udang vaname lebih sejahtera.

Pengeluaran rumah tangga petambak udang vaname di Desa Bratasena Adiwarna adalah sebesar Rp860.215,00 per kapita per bulan. Jika dibandingkan dengan garis kemiskinan masyarakat Lampung yaitu $\mathrm{Rp}$ 384.882,00 dan Kabupaten Tulang Bawang yaitu Rp373.681,00 per kapita per bulan (BPS Provinsi Lampung 2017), maka petambak di Desa Bratasena Adiwarna seluruhnya berada diatas garis kemiskinan.

\section{Faktor-faktor yang Mempengaruhi Tingkat Kesejahteraan}

Analisis binary logit digunakan karena variabel dependen terdiri dari dua kategori, yaitu rumah tangga petani sejahtera dan belum sejahtera. Variabel terikat $(\mathrm{Y})$ pada penelitian ini adalah kesejahteraan rumah tangga petambak udang vaname, dimana $\mathrm{Y}=0$ merupakan keluarga belum sejahtera dan $\mathrm{Y}=1$ merupakan keluarga sejahtera. Variabel bebas (X) pada penelitian ini adalah pendapatan rumah tangga (X1), jumlah tanggungan rumah tangga (X2), pendidikan (X3), pengalaman budi daya (X4), dan usia responden (X5). Berdasarkan analisis yang dilakukan, maka diperoleh hasil regresi binary logit dapat dilihat pada Tabel 3. 
Tabel 3. Hasil regresi binary logit faktor-faktor yang mempengaruhi kesejahteraan rumah tangga petambak udang vaname

\begin{tabular}{lrrrr}
\hline \multicolumn{1}{c}{ Variabel } & Coefici-ent & z-statistic & $\begin{array}{c}\text { Proba- } \\
\text { bility }\end{array}$ & $\begin{array}{l}\text { Odds } \\
\text { Ratio }\end{array}$ \\
\hline C & 14,769 & 1,6806 & 0,0928 & $\begin{array}{l}2.594 .9 \\
30\end{array}$ \\
$\begin{array}{l}\text { X1(Pendapa } \\
\text { tan RT) }\end{array}$ & $2,54 \mathrm{E}-07 * * *$ & 3,0648 & 0,0022 & 1,0000 \\
$\begin{array}{l}\text { X2(Jumlah } \\
\text { tanggungan }\end{array}$ & $-5,1646^{* * *}$ & $-3,3202$ & 0,0009 & 0,0057 \\
$\begin{array}{l}\text { RT) } \\
\text { X3(Pendidi- }\end{array}$ & 0,1448 & 0,6244 & 0,5323 & 1,1558 \\
$\begin{array}{l}\text { kan) } \\
\text { X4(Pengala- } \\
\text { man budi } \\
\text { daya) }\end{array}$ & 0,2143 & 0,8663 & 0,3863 & 1,2390 \\
$\begin{array}{l}\text { X5 (Usia } \\
\text { responden) }\end{array}$ & $-0,2833$ & $-1,3704$ & 0,1705 & 0,7532 \\
\hline $\begin{array}{l}\text { McFadden } \\
\text { R-squared }\end{array}$ & 0,6908 & & & \\
$\begin{array}{l}\text { LR statistic } \\
\text { Prob (LR } \\
\text { statistic) }\end{array}$ & 63,810 & & & \\
\hline Keterangan:***: taraf signifikansi 99 persen & & \\
\hline
\end{tabular}

Nilai McFadden R-squared sebesar 0,690897, artinya sebesar 69,08 persen variabel dependen (kesejahteraan petambak) dijelaskan oleh variabel independen (pendapatan rumah tangga, jumlah tanggungan rumah tangga, pendidikan, lama pengalaman budi daya, dan usia responden). Sisanya sebesar 30,92 persen dijelaskan oleh variabel lain yang tidak dimasukkan kedalam model.

Pengaruh variabel independen terhadap variabel dependen secara bersama-sama dapat diketahui dengan menggunakan uji LR statistik. Berdasarkan hasil regresi binary logit pada Tabel 5, dapat dilihat bahwa nilai probability LR statistik adalah 0,000000. Artinya, variabel pendapatan rumah tangga, jumlah tanggungan rumah tangga, pendidikan, pengalaman budi daya, dan usia responden secara bersama-sama berpengaruh nyata terhadap peluang rumah tangga petambak udang vaname di Desa Bratasena Adiwarna untuk sejahtera.

Uji parsial dilakukan untuk mengetahui apakah variabel independen berpengaruh nyata terhadap variabel dependen. Berdasarkan Tabel 5, diketahui bahwa variabel pendapatan rumah tangga memiliki nilai probabilitas sebesar 0,002 . Artinya faktor pendapatan rumah tangga berpengaruh terhadap peluang rumah tangga untuk sejahtera. Nilai odds ratio pendapatan rumah tangga (X1) adalah 1,0000 , sehingga peluang rumah tangga untuk sejahtera akan naik sebesar 1,0000kali setiap peningkatan pendapatan rumah tangga sebesar Rp1,00.

Variabel jumlah tanggungan rumah tangga memiliki nilai probabilitas sebesar 0,0009, sehingga faktor jumlah tanggungan rumah tangga berpengaruh terhadap peluang rumah tangga untuk sejahtera. Semakin kecil jumlah tanggungan rumah tangga maka pengeluaran akan semakin kecil. Nilai odds ratio jumlah tanggungan keluarga (X2) adalah 0,0057. Artinya peluang rumah tangga untuk sejahtera akan naik sebesar 0,0057kali setiap penurunan jumlah tanggungan rumah tangga sebesar satu jiwa.

Penelitian ini sejalan dengan penelitian Hartoyo, dan Aniri (2010) tentang tingkat kesejahteraan keluarga pembudidaya ikan dan nonpembudi daya ikan di Kabupaten Bogor. Hasil dari penelitian tersebut menunjukkan bahwa faktor yang berpengaruh signifikan terhadap tingkat kesejahteraan adalah pendapatan rumah tangga (positif) dan jumlah anggota keluarga (negatif)

\section{KESIMPULAN}

Rata-rata pendapatan hasil budi daya udang eks plasma PT Centralpertiwi Bahari pada periode I, II, dan III berturut-turut adalah Rp7.986.264, Rp13.868.109, dan Rp27.334.963. Rata-rata total pendapatan rumah tangga eks plasma PT Centralpertiwi Bahari adalah Rp64.902.569,00 per tahun, yang diperoleh dari 70 persen pendapatan udang, 10 persen pendapatan nonudang, 2 persen pendapatan off farm, dan 18 persen pendapatan nonfarm. Berdasarkan analisis tingkat kesejahteraan dengan indikator Sajogyo (1996) diketahui bahwa 37 persen petambak responden berada pada golongan cukup dan 63 persen berada pada golongan hidup layak. Berdasarkan garis kemiskinan BPS Lampung (2017), seluruh rumah tangga petambak udang vaname tergolong sebagai masyarakat tidak miskin. Tingkat kesejahteraan rumah tangga eks plasma PT Centralpertiwi Bahari dipengaruhi oleh pendapatan rumah tangga, dan jumlah tanggungan rumah tangga.

\section{DAFTAR PUSTAKA}

Badan Penelitian dan Pengembangan Kelautan dan Perikanan. 2014. Strategi Pengelolaan Pakan Pada Budi Daya Udang Vaname L. Vannamei. Balai Penelitian dan Pengembangan Budi Daya Air Payau. Jakarta. 
BPS [Badan Pusat Statistik]. 2015. Produksi Perikanan Budidaya Menurut Provinsi dan Jenis Budidaya (ton), 2000-2015. https://www.bps.go.id/statictable/2009/10/05 /1706/produksi-perikanan-budidayamenurut-provinsi-dan-jenis-budidaya-20002015.html. [05November 2017].

BPS [Badan Pusat Statistik] Provinsi Lampung. 2017. Garis Kemiskinan Provinsi Lampung menurut Kabupaten/Kota 2005-2017. https://lampung.bps.go.id/dynamictable/2016 /10/20/43/-dinamis-garis-kemiskinanprovinsi-lampung-menurut-kabupaten-kota2005---2016.html. [21Juli 2018].

BPS [Badan Pusat Statistik] Kabupaten Tulang Bawang. 2017. Kabupaten Tulang Bawang Dalam Angka Tahun 2016. https://tulangbawangkab.bps.go.id/publicatio n.html. [12 Mei 2018].

CPP [Central Proteina Prima]. 2016. Bidang Usaha Pertambakan. https://www.cpp.co. $\mathrm{id} / \mathrm{id} /$ our-business/integratedaquaculture/ cpb-farm. [3 Juni 2018].

Dinas Kelautan dan Perikanan Provinsi Lampung. 2016. Statistik Perikanan Budidaya Tahun 2016. Dinas Kelautan dan Perikanan Provinsi Lampung. Bandar Lampung.

Fadilah, Abidin Z, dan Kalsum U. 2014. Pendapatan dan kesejahteraan rumah tangga nelayan obor di Kota Bandar Lampung. JIIA, 2(1) : 71-76. http://jurnal.fp.unila.ac.id/ index.ph/JIA/article/view/563/525. [05 Desember 2017].

Hartoyo dan Aniri NB. 2010. Analisis tingkat kesejahteraan keluarga pembudidaya ikan dan nonpembudidaya ikan di Kabupaten Bogor. Jurnal Ilmu Keluarga dan Konsumen, 3(1): 64-73. http://journal.ipb.
ac.id/index.php/jikk/article/viewFile/5185/35 79. [05 Desember 2017].

Irianto H dan Mardikanto T. 2012. Metoda Penelitian dan Evaluasi Agribisnis. Jurusan /Program Studi Agribisnis UNS-Solo. Surakarta.

Kementerian Kelautan dan Perikanan. 2012. Budidaya Udang Vaname Intensif Pakai Mulsa. Direktorat Jendral Perikanan Budidaya. Jakarta Selatan. https://kkp.go. $\mathrm{id} /$. [02 November 2017].

Pulungan RH, Fauzia L, dan Emalisa. 2015. Analisis kelayakan usaha tambak udang (studi kasus : Desa Sei Meran, Kec. Pangkalan Susu, Kab. Langkat ). Jurnal USU. 4 (11): 1-12. https://jurnal.usu.ac.id/ index.php/ceress/article/view/14431/6342. [10 Desember 2017].

Sajogyo. 1996. Garis Kemiskinan dan Kebutuhan Minimum Pangan. Aditya Media. Yogyakarta.

Soekartawi. 2002. Analisis Usahatani. UI-Press. Universitas Indonesia.

Soekartawi. 2006. Analisis Usahatani. Universitas Indonesia. Jakarta.

Sarwono J. 2014. Riset Skripsi dan Tesis dengan SPSS 22. Elex Media Komputindo. Jakarta.

Susanti S, Lestari DAH, Kasymir E. 2017. Sistem Agribisnis Ikan Patin (Pangasius sp) Kelompok budidaya ikan Sekar Mina Di Kawasan Minapolitan Patin Kecamatan Kota Gajah Lampung Tengah. JIIA, 5(2) : 116123. http://jurnal.fp.unila.ac.id/index.php/ JIA/article/view/1648/1474. [12 Desember 2018].

Yuwono P. 2005 Pengantar Ekonometri. ANDI. Yogyakarta. 